\title{
The
}
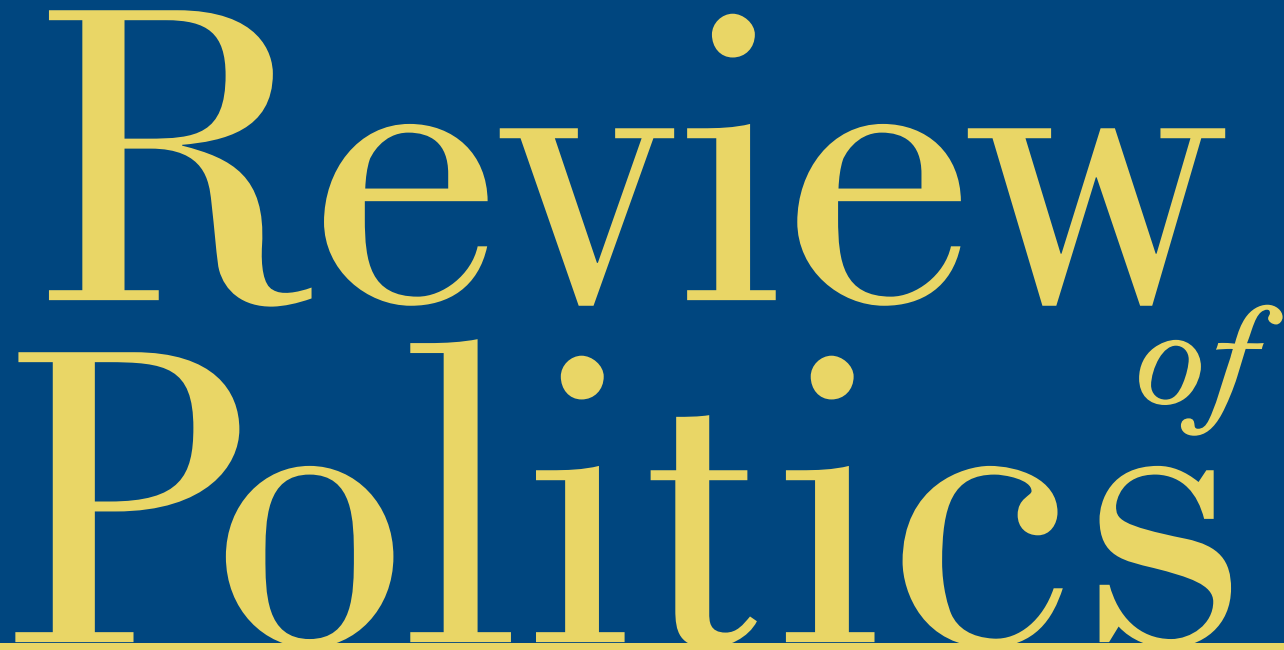

ARTICLES

Philip Stadter, “Alexander Hamilton's Notes on Plutarch in His Pay Book"

James W. Ceaser, "Alexis de Tocqueville and the Two-Founding Thesis" Matthew S. Brogdon, "Defending the Union: Andrew Jackson's

Nullification Proclamation and American Federalism"

George Thomas, "What Is Political Development? A Constitutional

Perspective"

Karen Orren and Stephen Skowronek, "A Reply: Have We

Abandoned a 'Constitutional Perspective' on American

Political Development?" with reply by George Thomas

Review Essay: D. Osei Robertson, "Two Steps Forward, One Step

Back: The Persistent Complexities of Race and Politics in the US" 


\title{
THE REVIEW OF POLITICS
}

\author{
Editor \\ CATHERINE H. ZUCKERT \\ Executive Associate Editor \\ DENNIS WM MORAN \\ Book Review Editor \\ PETER R. MOODY, JR. \\ Assistant Editor \\ LES HARRIS \\ Editorial Interns: \\ Matthew Holbreich \\ Faisal Baluch \\ Associate Editors
}

Fred Dallmayr

E.A. Goerner

A. James McAdams

Ruth M. Abbey

Daniel Philpott

James Turner

Former Editors

Waldemar Gurian

M.A. Fitzsimons

Thomas Stritch

Frederick J. Crosson

Donald P. Kommers

Walter Nicgorski

Editorial Advisory Board

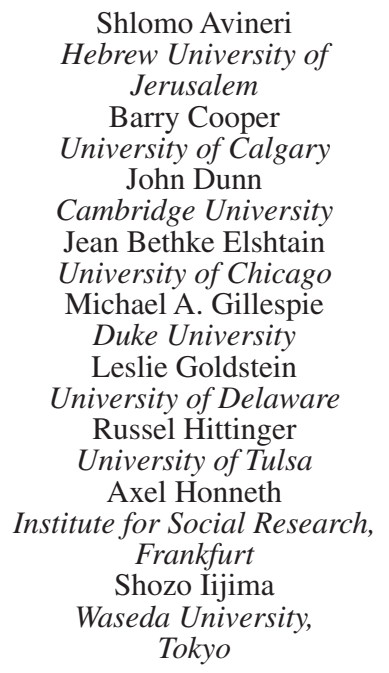

Ramin Jahanbegloo

University of Toronto Pierre Manent

L'Ecole des Hautes Etudes en sciences sociales

Harvey C. Mansfield

Harvard University

Mary Nichols

Baylor University

Bruce M. Russett

Yale University

Arlene Saxonhouse

University of Michigan

Steven B. Smith

Yale University

Peter Steinberger

Reed College

John Witte, Jr.

Emory University

Jean M. Yarbrough

Bowdoin College

Administrative Assistant: Kelli Brown

The Review of Politics publishes primarily philosophical and historical studies of politics, especially those concentrating on political theory and American political thought. The journal also includes thoughtful scholarly reflections on all aspects of politics-including analysis of institutions and techniques, international relations, comparative politics, literary reflections on politics or political interpretations of literary works, constitutional theory and practices. 


\section{TABLE OF CONTENTS SPRING 2011}

Vol. 73

SPRING 2011

No. 2

Philip Stadter

Alexander Hamilton's Notes on Plutarch

in His Pay Book

James W. Ceaser

Alexis de Tocqueville and the Two-Founding Thesis . . . . . 219

Matthew S. Brogdon

Defending the Union: Andrew Jackson's Nullification

Proclamation and American Federalism . . . . . . . . . . 245

George Thomas

What Is Political Development? A Constitutional

Perspective ... . . . . . . . . . . . . . . . . . 275

Karen Orren and Stephen Skowronek

Have We Abandoned a "Constitutional

Perspective" on American Political Development? . . . . . 295

George Thomas

A Reply to Orren and Skowronek . . . . . . . . . . . . . 301

Review Essay:

D. Osei Robertson

Two Steps Forward, One Step Back: The Persistent

Complexities of Race and Politics in the US . . . . . . . 305

Reviews:

Christopher S. Stowe: THE UNION CAUSE

Review of Joan Waugh's U. S. Grant: American Hero,

American Myth.

Kevin Walker: DEMOCRACY DISENCHANTED

Review of Steven D. Smith's The Disenchantment

of Secular Discourse . . . . . . . . . . . . . . . . . . . . . . . . . . . . 325

P. A. Hayman: THE RELEVANT HISTORY OF RIGHTS

Review of Samuel Moyn's The Last Utopia: Human Rights in History. ... 


\section{Samuel B. Hoff: DIAGNOSING OUR PRESENT}

\section{DISCONTENTS}

Review of Paul A. Rahe's Montesquieu and the Logic of Liberty:

War, Religion, Commerce, Climate, Terrain, Technology, Uneasiness of Mind, the Spirit of Political Vigilance, and the Foundations of the Modern Republic

Hideko Magara: DEMOCRACY WITHOUT

\section{ACCOUNTABILITY}

Review of Frances McCall Rosenbluth and Michael F. Thies's

Japan Transformed: Political Change and Economic Restructuring . . . . . 333

Claude Pomerleau: POPULIST AUTHORITARIAN

Review of Leslie C. Gates's Electing Chávez: The Business of Anti-neoliberal Politics in Venezuela . . . . . . . . . . . . . . . . 336

Howard Williams: MORALITY AND RIGHT

Review of Arthur Ripstein's Force and Freedom . . . . . . . . . . . . . . . 339

Jessica C. Teets: WORKING WITHIN THE SYSTEM

Review of Teresa Wright's Accepting Authoritarianism:

State-Society Relations in China's Reform Era . . . . . . . . . . . . . . 342

Elliot Bartky: WHY THE JEWS?

Review of C. Fred Alford's After the Holocaust: The Book of Job,

Primo Levi, and the Path to Affliction ..

Jenny Adams: SACRED RULERSHIP

Review of Francis Oakley's Empty Bottles of Gentilism: Kingship

and the Divine in Late Antiquity and the Early Middle Ages (to 1050) . . 350

Manfred Henningsen: END TIMES

Review of John R. Hall's Apocalypse: From Antiquity to the

Empire of Modernity . . . . . . . . . . . . . . . . . . . . . . . . . . . 352

Robert S. Snyder: CHANGING NORMS OF RECOGNITION

Review of Mikulas Fabry's Recognizing States: International Society and the Establishment of New States Since 1776 . . . . . . . . . . 355

Dean J. Kotlowski: NOT SIMPLY JOHNSON'S WAR Review of Andrew L. Johns's Vietnam's Second Front: Domestic Politics, the Republican Party, and the War. . . . . . . . . . . 358

Jeffrey Record: WE SHOULD HAVE KNOWN Review of James H. Lebovic's The Limits of U.S. Military Capability: Lessons from Vietnam and Iraq . . . . . . . . . . . . . 360

David D. Corey: HEALTHY SHAME

Review of Christina H. Tarnopolsky's Prudes, Perverts, and Tyrants: Plato's "Gorgias" and the Politics of Shame . . . . . . . . 362

Ian Angus: THE EXONERATION OF SOCRATES

Review of David N. McNeill's An Image of the Soul in Speech:

Plato and the Problem of Socrates 


\section{CONTRIBUTORS TO THIS ISSUE}

PHILIP STADTER is Professor of Classics Emeritus at University of North Carolina, Chapel Hill. JAMES W. CEASER is Professor of Politics at University of Virginia. MATTHEW S. BROGDON is Lecturer in Political Science at Baylor University. GEORGE THOMAS is Associate Professor in the Department of Government at Claremont McKenna College. KAREN ORREN is Professor of Political Science at University of California, Los Angeles. STEPHEN SKOWRONEK is Professor of Political Science at Yale University.

D. OSEI ROBERTSON is Assistant Professor of Government at Bowie State University. CHRISTOPHER S. STOWE is Associate Professor in the Department of Military History at the United States Army Command and General Staff College. KEVIN WALKER is Visiting Assistant Professor of Political Science at Emmanuel College. P. A. HAYMAN is Associate Lecturer at the Open University, United Kingdom. SAMUEL B. HOFF is George Washington Distinguished Professor, Department of History, Political Science, and Philosophy at Delaware State University. HIDEKO MAGARA is Professor of Political Science and Economics at Waseda University. CLAUDE POMERLEAU, CSC, is Associate Professor of Political Science at University of Portland. HOWARD WILLIAMS is Deputy Director of Postgraduate Studies and International Relations at Aberystwyth University. JESSICA

C. TEETS is Assistant Professor of Political Science at Middlebury College. ELLIOT BARTKY is Assistant Professor of Political Science at Indiana University-Purdue University, Fort Wayne. JENNY ADAMS is Associate Professor of English at University of Massachusetts. MANFRED HENNINGSEN is Professor of Political Science at the University of Hawaii at Manoa. ROBERT S. SNYDER is Professor of Political Science at Southwestern University. DEAN J. KOTLOWSKI is Professor of History at Salisbury University. JEFFREY RECORD is Professor of Strategy at the Strategic Studies 
Institute, United States Army Air War College. DAVID D. COREY is Associate Professor of Political Science at Baylor University and Bell Distinguished Visiting Professor at University of Tulsa. IAN ANGUS is Professor in the Department of Humanities at Simon Fraser University. 
Subscription Information: The Review of Politics (ISSN 0034-6705) is published quarterly in February, May, August and November by Cambridge University Press, 32 Avenue of the Americas, New York, NY 10013-2473 USA/The Edinburgh Building, Shaftesbury Road, Cambridge CB2 8RU, UK for the University of Notre Dame. Annual subscription rates for Volume 73 (2011): Institutional subscription rates, print and online: US $\$ 128.00$ in the USA, Canada, and Mexico; UK $£ 73.00+$ VAT elsewhere. Institutional subscription rates, online only: US $\$ 116.00$ in the USA, Canada, and Mexico; UK £62.00 + VAT elsewhere. Institutional subscription rates, print only: US $\$ 123.00$ in the USA, Canada, and Mexico; UK $£ 66.00+$ VAT elsewhere. Individual subscription rates, print only: US $\$ 38.00$ in the USA, Canada, and Mexico; UK $£ 19.00$ + VAT elsewhere. Correspondence concerning subscriptions should be sent to: Cambridge University Press, 100 Brook Hill Drive, West Nyack, NY 10994, USA for customers in the USA, Canada, or Mexico. Customers elsewhere should contact: Cambridge University Press, The Edinburgh Building, Shaftesbury Road, Cambridge CB2 8RU, UK.

Editorial Office: All correspondence concerning submissions and manuscripts under review should be sent to The Review of Politics, University of Notre Dame, 547 Flanner Hall, Notre Dame, IN 46556. Phone: 574-631-6623. Email: ROP.Editor.1@nd.edu. Website: www.nd.edu/ rop

Abstracting and Indexing Information: Articles in The Review of Politics are indexed in the International Index to Periodicals and the Catholic Periodicals and Literature Index; abstracted in the International Political Science Abstracts; and abstracted and indexed in ABC POL. SCI., Historical Abstracts, Social Science Index (also available in the electronic versions), Book Review Index, and International Bibliography of the Social Sciences.

Copyright (C) 2011 University of Notre Dame. All rights reserved. No part of this publication may be reproduced, in any form or by any means, electronic, photocopy, or otherwise, without permission in writing from Cambridge University Press, Rights and Permissions Manager, 32 Avenue of the Americas, New York, NY 10013-2473 USA. For further information see http://us.cambridge/org/information/rights/.

Periodicals postage paid in New York, NY and additional mailing offices. Postmaster: Send address changes to The Review of Politics, Cambridge University Press, 100 Brook Hill Drive, West Nyack, NY 10994-2133 USA.

Photocopying information for users in the U.S.A.: the Item-Fee Code for the publication (0034-6705/11 \$9.00+.10) indicates that copying for internal or personal use beyond that permitted by Sec. 107 or 108 of the U.S. Copyright Law is authorized for users duly registered with the Copyright Clearance Center (CCC) provided that the appropriate remittance of $\$ 9.00$ per article is paid directly to CCC, 222 Rosewood Drive, Danvers, MA 01923. Specific written permission must be obtained for all other copying. 